\title{
Intestinal Secretion Induced by Vasoactive Intestinal Polypeptide
}

\author{
A COMPARISON WITH CHOLERA TOXIN IN THE CANINE JEJUNUM IN VIVO
}

\author{
Guenter J. Krejs, Ronald M. Barkley, Nicholas W. Read, and John S. Fordtran, \\ Department of Internal Medicine, University of Texas Health Science Center \\ at Dallas, Southwestern Medical School, Dallas, Texas 75235
}

A B S T RACT The effect of vasoactive intestinal polypeptide (VIP) on intestinal water and electrolyte transport and transmucosal potential difference was investigated in the dog jejunum in vivo and compared to secretion induced by cholera toxin. Isolated jejunal loops were perfused with a plasma-like electrolyte solution. VIP $(0.08 \mu \mathrm{g} / \mathrm{kg}$ per min) was administered directly into the superior mesenteric artery by continuous infusion over $1 \mathrm{~h}$. From a dye dilution method, it was estimated that a mean plasma VIP concentration of $12,460 \mathrm{pg} / \mathrm{ml}$ reached the loops. VIP caused secretion of water and electrolytes; for example, chloride: control, $8 \mu \mathrm{eq} / \mathrm{cm}$ per h absorption; VIP, $92 \mu \mathrm{eq} /$ $\mathrm{cm}$ per h secretion. A marked increase in transmucosal potential difference (control, $-1.0 \mathrm{mV}$; VIP, $-5.9 \mathrm{mV}$, lumen negative) occurred within $1 \mathrm{~min}$ after starting VIP infusion. Analysis of unidirectional fluxes showed increased plasma-to-lumen flux of sodium and chloride and decreased lumen-to-plasma flux of sodium. Chloride and bicarbonate were actively secreted against an electrochemical gradient. Although sodium secretion occurred down an electrochemical gradient, flux ratio analysis suggested a component of active sodium secretion. VIP caused a slight increase in protein output into the loops; light microscopy revealed capillary dilatation and closed intercellular spaces. The effect of VIP was readily reversible. Except for the delayed onset of secretion, the effect of cholera toxin was qualitatively similar to VIP; however, capillary dilatation and increased protein output were not noted with cholera toxin.

\section{INTRODUCTION}

Vasoactive intestinal polypeptide $(\mathrm{VIP})^{1}$ and cholera toxin (CT) are implicated in the pathogenesis of severe

Received for publication 21 October 1977 and in revised form 16 December 1977.

'Abbreviations used in this paper: BSP, bromsulphalein; CT, cholera toxin; PD, potential difference; SMA, superior mesenteric artery; VIP, vasoactive intestinal polypeptide. life threatening forms of diarrhea. The results of previous studies have suggested that both agents cause secretion by activating the adenylate cyclase-cAMP system $(1,2)$. Although intestinal secretion caused by CT has been extensively studied in vivo, there are only limited data available on VIP-induced secretion in vivo (3-5). In particular, there are no previous reports on unidirectional ion fluxes and transmucosal potential difference in response to VIP, and it is not known which ions are secreted actively in response to high blood concentrations of this peptide.

In the present study, we have compared the effect of VIP and CT on water and electrolyte movement, transmucosal potential difference and mucosal integrity in the canine jejunum in vivo. VIP was infused directly into the superior mesenteric artery in order to rapidly reach and easily maintain a high concentration of the peptide in the intestinal arterioles, while minimizing its systemic effects.

\section{METHODS}

Experiments were carried out on healthy, dewormed, and 18 -h fasted mongrel dogs weighing $15-30 \mathrm{~kg}$. Anesthesia was administered with i.v. pentobarbital sodium, and respiration was controlled by means of a large volume animal respirator (model 613, Harvard Apparatus Co., Millis, Mass.). Laparotomy was performed and two adjacent jejunal loops of $25-\mathrm{cm}$ length were isolated, commencing $20 \mathrm{~cm}$ from the ligament of Treitz. Teflon spools, attached to wide bore polyethylene tubing (inside diameter $4 \mathrm{~mm}$ ), were tied in place at the ends of each loop (Fig. 1). The gut proximal to these loops was allowed to drain externally through a similar spool and tubing. The small intestine distal to the loops was closed. The loops were left inside the peritoneal cavity and the abdomen was kept closed during the perfusion periods; the tubes were brought out through stab wounds.

In each experiment, a fine polyethylene catheter (inside diameter $0.011 \mathrm{~mm}$ ) was inserted through a distal radical of the superior mesenteric artery (SMA) between the loops and advanced retrograde until its tip was in the main trunk of the SMA. The correct position of the catheter was confirmed by briefly infusing bromsulphalein (BSP $35 \mathrm{mg} / \mathrm{ml}$ ) at a rate of $0.76 \mathrm{ml} / \mathrm{min}$ using a Harvard pump (model 931, Harvard Apparatus $\mathrm{Co}$.). The concentration of BSP was then estimated in 


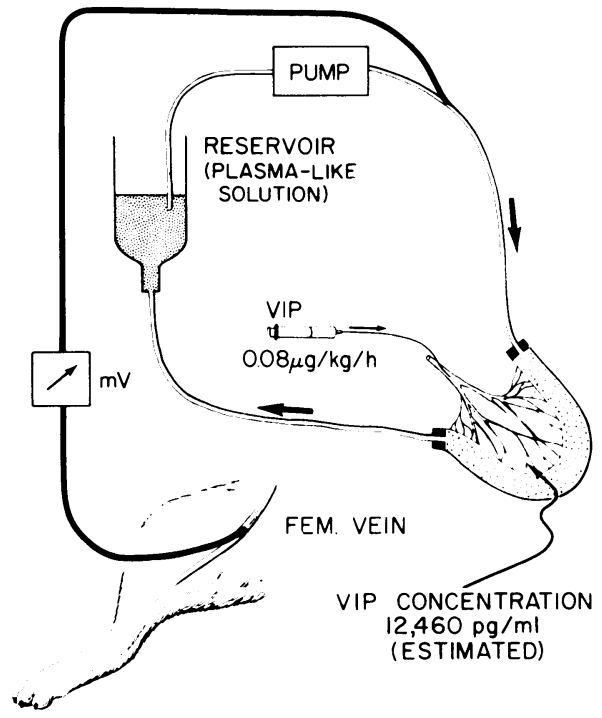

FIGURE 1 Experimental setup for in vivo perfusion of jejunal loops and for measurement of transmucosal PD. (Two loops were constructed for each dog, but only one is shown in this figure.) VIP was infused into the main trunk of the SMA. In the cholera series, CT was added directly to the perfusate. The reservoir was bubbled with a mixture of $5 \% \mathrm{CO}_{2}$ and $9.5 \% \mathrm{O}_{2}$, which is not shown in the picture.

samples from arterial radicals proximal to, distal to, and between the loops. (The dilution of BSP was later used to estimate the concentration of VIP reaching the loops.) Thereafter, the arterial catheter was used to infuse saline $(154 \mathrm{mM} \mathrm{NaCl})$ with or without VIP at a rate of $0.76 \mathrm{ml} / \mathrm{min}$.

In all experiments, a plasma-like perfusate $(175 \mathrm{ml})$ was continuously recirculated $(16 \mathrm{ml} / \mathrm{min})$ through the loops from glass reservoirs (maintained at $37^{\circ} \mathrm{C}$ ) by means of a peristaltic pump. Intraluminal pressure in the loops was kept constant between 4 and $6 \mathrm{~cm}$ of $\mathrm{H}_{2} \mathrm{O}$ by adjusting the fluid level in the reservoirs (Fig. 1). The perfusate had the following composition: $\mathrm{Na}^{\prime}, 135 ; \mathrm{K}^{+}, 5 ; \mathrm{Cl}^{-}, 115 ; \mathrm{HCO}_{3}^{-}, 25 \mathrm{med} /$ liter; polyethylene glycol, $5 \mathrm{~g}$ /liter; and $1 \mu \mathrm{Ci} /$ liter each of ${ }^{22} \mathrm{Na}$ and ${ }^{36} \mathrm{Cl}$. The reservoirs were bubbled with a mixture of $5 \% \mathrm{CO}_{2}$ and $95 \% \mathrm{O}_{2}$, which yielded a $\mathrm{PCO}_{2}$ of about $40 \mathrm{~mm} \mathrm{Hg}$ and also served to mix the fluid. After an equilibration period of $15 \mathrm{~min}$, an initial $12-\mathrm{ml}$ sample of perfusate was removed for analysis. The solution was then recirculated for a test period of $\mathrm{l} \mathrm{h}$ before a final sample was withdrawn. Then the loops were drained and flushed with air before filling with a fresh solution.

In the VIP experiments, carried out in five dogs (10 loops), there were two control periods, separated by a test period during which VIP2 was infused into the SMA at a rate of $0.08 \mu \mathrm{g} / \mathrm{kg}$ per min. ${ }^{3}$ The calculated mean concentration of

${ }^{2}$ VIP was provided by Gastrointestinal Hormone Resources, National Institute of Arthritis, Metabolism, and Digestive Diseases, Bethesda, Md., and originated from the Gastrointestinal Hormone Research Unit, Karolinska Institutet, Stockholm, Sweden (Dr. V. Mutt).

${ }^{3}$ This dose was chosen after preliminary experiments had shown that a lower dose $(0.02 \mu \mathrm{g} / \mathrm{kg}$ per min) only abolished absorption (zero net $\mathrm{H}_{2} \mathrm{O}$ movement in one dog) whereas a higher dose $(0.24 \mu \mathrm{g} / \mathrm{kg}$ per min) caused engorgement of the loops in another dog.
$V I P$ reaching the loop was 12,460 (range $8,000-15,700$ ) $\mathrm{pg} /$ $\mathrm{ml}{ }^{*}$ The BSP and VIP concentration in the infused material was known; from the dilution of BSP in the mesenteric artery, the VIP concentration arriving at the mucosa was estimated, assuming that there was no disappearance of VIP from plasma in the precapillary vascular bed. Full thickness biopsies were taken from each loop at construction and after each perfusion period. These were fixed in formalin for histological examination.

Experiments with purified CT $^{5}$ were carried out in five dogs (10) loops). Differences in the protocol compared to the VIP experiments were necessary because secretion is delayed for at least $1 \mathrm{~h}$ after luminal administration of the toxin $(8$, 9) and cannot be reversed by its withdrawal (10). Therefore, after an initial $1-\mathrm{h}$ control period, $100 \mu \mathrm{g}$ of cholera toxin was added to the perfusate, which was recirculated for further $1.5 \mathrm{~h}$. The loops were drained and refilled with fresh plasma-like solution before two test periods carried out from 2 to 3 and from 6 to $7 \mathrm{~h}$ after exposure to the toxin. Throughout the experiment, saline was infused into the SMA (to mimic the VIP studies) and biopsies were taken at construction and after each perfusion period.

In all experiments, arterial $\mathrm{pH}$ and $\mathrm{PCO}_{2}$, serum concentrations of $\mathrm{Na}^{+}, \mathrm{K}^{+}, \mathrm{Cl}^{-}$, and $\mathrm{HCO}_{3}^{-}$and serum osmolality were measured hourly. The electrocardiogram and arterial blood pressure were recorded continuously on a monitor. Sufficient Ringer's lactate was infused through a peripheral vein to maintain a diuresis of $20-40 \mathrm{ml} / \mathrm{h}$ and to keep the central venous pressure between 6 and $12 \mathrm{~cm} \mathrm{H}_{2} \mathrm{O}$. A thermal blanket and a heating lamp were used to maintain body temperature $\left(38^{\circ} \mathrm{C}\right)$, which was monitored with a telethermoneter in the rectum.

Measurement of the transmucosal potential difference $(P D)$. The transmucosal PD was recorded by a modification of the method described previously (11). Briefly, the perfusate itself acted as a flowing intraluminal electrode while the indifferent, or reference, electrode was the infusion of Ringer's lactate into a peripheral vein. These electrodes were connected via salt agar bridges $(2 \mathrm{M} \mathrm{KCl}$ in $3 \%$ agar) and balanced calomel half-cells back-to-back across the input terminals of a battery-powered electrometer (model 602. Keithley Instruments Inc., Cleveland, Ohio), the output of which was displayed on a chart recorder (model B-261, Rikadenki Kogyo Co., Tokyo, Japan).

Calculation of net and unidirectional movement of water and ions. The analysis of samples has been described previously (12). Polyethylene glycol served as a nonabsorbable marker and was used for calculating net water and solute movement $(13,14)$. Polyethylene glycol recovery determined in 14 perfusion periods (control and VIP periods) was 100.4 $\pm 0.7 \%$ (mean \pm SEM)

Lumen-to-plasma unidirectional fluxes for $\mathrm{Na}^{+}$and $\mathrm{Cl}^{-}$were calculated with the equation described by Berger and Steele (15). Plasma-to-lumen flux was calculated from the difference between net movement and lumen-to-plasma flux, assuming that the plasma volume constitutes an infinite pool with zero isotope concentration. This was proven by determining the radioactivity in the serum, which never rose above background levels. The observed flux ratios (lumen-to-plasma/

${ }^{4}$ It should be noted that we found jejunal secretion in vivo at a dose that was more than 150 times smaller than the concentration recpuired for in vitro studies (1).

${ }^{5}$ Purified CT was a gift of R. A. Finkelstein, Ph.D., University of Texas Southwestern Medical School, Dallas, Tex., and was prepared by his previously described procedure $(6,7)$. 
plasma-to-lumen flux) were compared to those calculated by Ussing's equation for passive ion movement (16).

Protein output into perfusate. The degree of protein leakage into each loop was estimated from the difference in total protein content (17) at the beginning and end of each test period.

Histology. The histological sections (4 $\mu \mathrm{m}$ thick), stained with hematoxylin-eosin, were coded and read by three independent observers. The sections were scored on a scale from 0 to 3 for integrity of the epithelial layer, width of intercellular spaces, and degree of capillary dilatation.

Statistical methods. The values obtained from each loop were subjected to statistical analysis (10 observations in five dogs of each VIP and CT series). A paired $t$ test was used to compare transport data from control and test periods. Because scores of the histological evaluation did not satisfy the assumptions for a parametric test, Kruskal-Wallis one-way analysis of variance (18) was used to examine any difference in biopsies taken from control, VIP, or CT periods. Computer curve fitting (examining linear, exponential, and polygonal functions) was employed to find the best correlation between PD and net water movement.

\section{RESULTS}

Effect of VIP. VIP caused an increase in transmucosal PD; the lumen became more negative by about $5 \mathrm{mV}$ (Table I). The PD change induced by intra-arterial VIP was rapid (within $1 \mathrm{~min}$ ) and initially amounted to as much as $10 \mathrm{mV}$ in individual dogs (Fig. 2 ). The PD returned promptly to basal values when the infusion was discontinued.

VIP induced profound fluid secretion into the jejunal loops. This was accompanied by secretion of chloride, bicarbonate, sodium, and potassium (Table I). Data on chloride transport, which is of particular interest for reasons explained in the following paragraph, are shown in Fig. 3. Before the infusion of VIP, chloride was absorbed ( $8 \mu \mathrm{eq} / \mathrm{cm}$ per $\mathrm{h})$, whereas secretion occurred during the VIP period (92 $\mu \mathrm{eq} / \mathrm{cm}$ per $\mathrm{h}$ ); when VIP was stopped, chloride was again absorbed ( $4 \mu \mathrm{eq} /$ cm per h).

TABLE I

Effect of VIP and CT on PD, Water, and Ion Movement

\begin{tabular}{|c|c|c|c|c|c|c|}
\hline & $\begin{array}{c}\text { Initial } \\
\text { control } \\
\text { perfusion }\end{array}$ & $\begin{array}{c}\text { VIP } \\
\text { infusion }\end{array}$ & $\begin{array}{c}\text { Final } \\
\text { control } \\
\text { perfusion }\end{array}$ & $\begin{array}{l}\text { Control } \\
\text { perfusion }\end{array}$ & $\begin{array}{c}\text { Perfusion } \\
2-3 \mathrm{~h} \\
\text { after CT }\end{array}$ & $\begin{array}{c}\text { Perfusion } \\
6-7 \mathrm{~h} \\
\text { after } \mathrm{CT}\end{array}$ \\
\hline $\mathrm{PD}, m V$ & $\begin{array}{l}-1.0 \\
\pm 0.5\end{array}$ & $\begin{array}{l}-5.9 * \\
\pm 0.6\end{array}$ & $\begin{array}{l}-0.5 \\
\pm 0.6\end{array}$ & $\begin{array}{l}-0.5 \\
\pm 0.5\end{array}$ & $\begin{array}{l}-4.2^{*} \\
\pm 0.7\end{array}$ & $\begin{array}{l}-7.1 * \\
\pm 0.7\end{array}$ \\
\hline $\mathrm{H}_{2} \mathrm{O}$ movement, $\mu \mathrm{l} / \mathrm{cm} / \mathrm{h}$ & $\begin{array}{r}-300 \\
\pm 48\end{array}$ & $\begin{array}{l}+648^{*} \\
\pm 160\end{array}$ & $\begin{array}{r}-304 \\
\pm 84\end{array}$ & $\begin{array}{r}-428 \\
\pm 88\end{array}$ & $\begin{array}{l}+2601 \\
\pm 160\end{array}$ & $\begin{array}{l}+976^{*} \\
\pm 192\end{array}$ \\
\hline $\mathrm{Na}^{+}$net movement, $\mu \mathrm{eq} / \mathrm{cm} / \mathrm{h}$ & $\begin{array}{r}-32 \\
\pm 8\end{array}$ & $\begin{array}{c}+121^{*} \\
\pm 28\end{array}$ & $\begin{array}{l}-20 \\
\pm 12\end{array}$ & $\begin{array}{l}-40 \\
\pm 12\end{array}$ & $\begin{array}{l}+44 \ddagger \\
\pm 24\end{array}$ & $\begin{array}{c}+136^{*} \\
\pm 28\end{array}$ \\
\hline $\mathrm{Na}^{+}$lumen to plasma, $\mu \mathrm{eq} / \mathrm{cm} / \mathrm{h}$ & $\begin{array}{r}104 \\
\pm 8\end{array}$ & $\begin{aligned} & 53^{*} \\
\pm & 12\end{aligned}$ & $\begin{array}{r}80 \\
\pm 16\end{array}$ & $\begin{array}{r}148 \\
\pm 28\end{array}$ & $\begin{array}{r}84 \\
\pm 8\end{array}$ & $\begin{aligned} & 36^{*} \\
\pm & 12\end{aligned}$ \\
\hline $\mathrm{Na}^{+}$plasma to lumen, $\mu e q / \mathrm{cm} / \mathrm{h}$ & $\begin{array}{r}72 \\
\pm 12\end{array}$ & $\begin{array}{l}174 \oint \\
\pm 12\end{array}$ & $\begin{array}{r}60 \\
\pm 8\end{array}$ & $\begin{array}{r}108 \\
\pm 20\end{array}$ & $\begin{array}{r}128 \\
\pm 36\end{array}$ & $\begin{array}{l}172 \ddagger \\
\pm 32\end{array}$ \\
\hline $\mathrm{Cl}^{-}$net movement, $\mu$ eq $/ \mathrm{cm} / \mathrm{h}$ & $\begin{array}{l}-8 \\
\pm 8\end{array}$ & $\begin{array}{l}+92 * \\
\pm 20\end{array}$ & $\begin{array}{l}-4 \\
\pm 8\end{array}$ & $\begin{array}{l}-40 \\
\pm 14\end{array}$ & $\begin{array}{l}+32 \\
\pm 32\end{array}$ & $\begin{array}{l}+96 \oint \\
\pm 25\end{array}$ \\
\hline $\mathrm{Cl}^{-}$lumen to plasma, $\mu \mathrm{eq} / \mathrm{cm} / \mathrm{h}$ & $\begin{array}{r}68 \\
\pm 8\end{array}$ & $\begin{array}{r}48 \\
\pm 8\end{array}$ & $\begin{array}{r}72 \\
\pm 12\end{array}$ & $\begin{array}{r}100 \\
\pm 20\end{array}$ & $\begin{array}{r}44 \ddagger \\
\pm 12\end{array}$ & $\begin{array}{l}36 \S \\
\pm 8\end{array}$ \\
\hline $\mathrm{Cl}^{-}$plasma to lumen, $\mu e q / \mathrm{cm} / \mathrm{h}$ & $\begin{array}{r}60 \\
+12\end{array}$ & $\begin{array}{l}140 \S \\
\pm 24\end{array}$ & $\begin{array}{r}68 \\
\pm 8\end{array}$ & $\begin{array}{r}60 \\
\pm 20\end{array}$ & $\begin{array}{r}76 \\
\pm 28\end{array}$ & $\begin{array}{l}132 \oint \\
\pm 28\end{array}$ \\
\hline $\mathrm{HCO}_{3}^{-}$net movement, $\mu \mathrm{eq} / \mathrm{cm} / \mathrm{h}$ & $\begin{array}{r}-12 \\
\pm 4\end{array}$ & $\begin{array}{c}+24^{*} \\
\pm 4\end{array}$ & $\begin{array}{l}-8 \\
\pm 4\end{array}$ & $\begin{array}{r}-12 \\
\pm 4\end{array}$ & $\begin{array}{c}+28 \S \\
\pm 8\end{array}$ & $\begin{array}{c}+40^{*} \\
\pm 8\end{array}$ \\
\hline $\mathrm{K}^{+}$net movement, $\mu \mathrm{eq} / \mathrm{cm} / \mathrm{h}$ & $\begin{array}{l}-0.24 \\
\pm 0.4\end{array}$ & $\begin{array}{l}+4.4^{*} \\
\pm 0.8\end{array}$ & $\begin{array}{l}-0.12 \\
\pm 0.4\end{array}$ & $\begin{array}{l}-1.6 \\
\pm 0.7\end{array}$ & $\begin{array}{l}+2.1 \ddagger \\
\pm 0.8\end{array}$ & $\begin{array}{l}+6.5^{*} \\
\pm 1.0\end{array}$ \\
\hline
\end{tabular}

Values are mean \pm SEM of 10 loops (five dogs). Water and electrolyte movement is given per centimeter length of jejunum per hour. Minus indicates absorption, plus indicates secretion. Statistical significance was determined for the difference between initial control period and perfusion period during VIP infusion, or between 2 and 3 , or between 6 and $7 \mathrm{~h}$ after exposure of the loops to toxin, respectively. ${ }^{*} P<0.001$.

$\ddagger P<0.05$.

$\$ P<0.01$. 

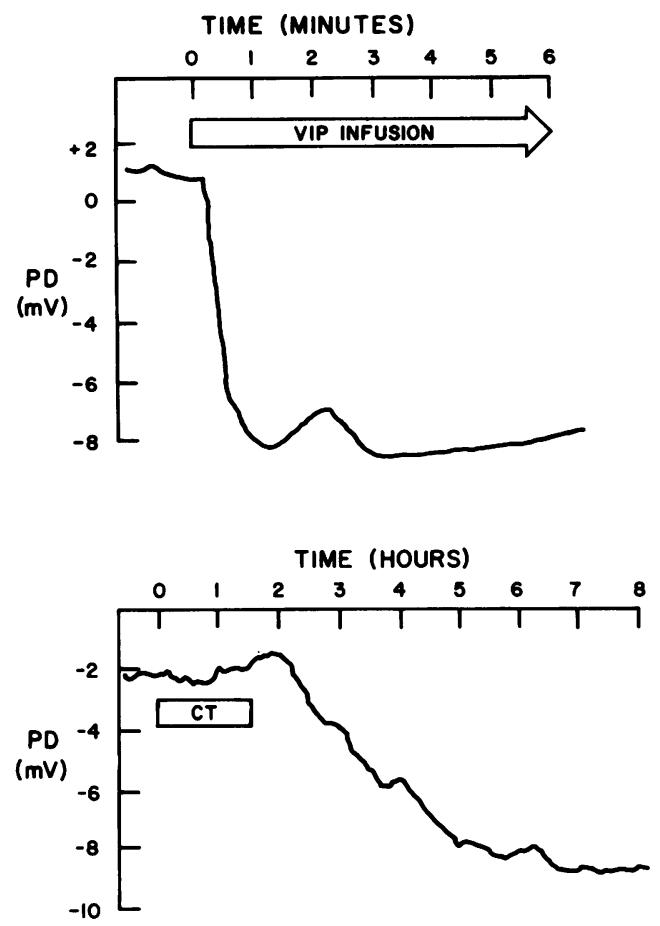

Figure 2 Typical examples of PD tracing in jejunal loops exposed to VIP (top) and CT (bottom). Note that the horizontal axis gives time in minutes with VIP experiment and in hours with CT experiment. When VIP was infused intraarterially, a marked change in PD occurred within $1 \mathrm{~min}$ When CT was given (bottom), a change in PD occurred only after a 2-h lag period. Between hours 2 and 6 , after exposure of the loop to CT, the PD became progressively more negative, finally leveling at a new base line.

Analysis of unidirectional fluxes revealed that chloride secretion resulted primarily from increased plasmato-lumen flux while the decrease in chloride lumento-plasma flux was not significant. Intraluminal concentrations of chloride and bicarbonate were above plasma levels and rose still further; ${ }^{6}$ as already noted the PD became more lumen negative during VIP-induced secretion (Tables I and II). Thus it is evident that secretion of chloride and bicarbonate in response to VIP was active against an electrochemical gradient. Furthermore, during the test period with VIP there was a profound discrepancy between observed and calculated flux ratios for chloride $(P<0.001)$, again indicating active chloride secretion (Table III).

Sodium secretion resulted from both reduction in

${ }^{6}$ In contrast to the rise in $\mathrm{Cl}^{-}$concentration during secretion which suggests active transport, the rise in luminal $\mathrm{Cl}^{-}$ concentration during the control period (Table II) was due to the fact that the perfusate was hypotonic to plasma (265 and $300 \mathrm{mosmol} / \mathrm{kg}$, respectively). This osmotic gradient favored water absorption and thus increased the luminal electrolyte concentration (secretion occurred against this osmotic gradient).

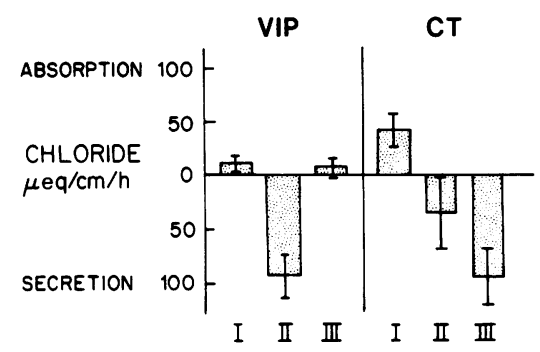

FIgURE 3 Chloride movement in the jejunum in response to VIP (left) and CT (right). In the initial control period (period I), there was absorption (bar above horizontal line) in both series. VIP infusion caused secretion (period II), and absorption was again observed after discontinuation of VIP administration (period III). CT led to progressive chloride secretion between 2 and 3 (II) and 6 and 7 (III) h after exposure of the loops to the toxin.

lumen-to-plasma flux and enhancement of the opposite plasma-to-lumen flux. Sodium secretion during VIP infusion occurred in a direction that was favored by both electrical and concentration gradients (Tables I and II). However, observed and calculated flux ratios for sodium differed significantly during the VIP period, which suggests at least some active secretion of sodium (Table III).

As shown in Table IV, protein output during VIP administration increased from a control value of 180 \pm 32 to $420 \pm 76 \mu \mathrm{g} / \mathrm{cm}$ per $\mathrm{h}(P<0.01)$. However, examination of histological sections showed no evidence of epithelial damage during the VIP test period compared to the control period (Table V). Although mucosal capillaries were dilated in response to VIP, there was no dilatation of intercellular spaces (Fig. 4, Table V).

Effect of CT. Jejunal secretion induced by CT was similar to that observed with VIP (Table I, Fig. 3). A small difference between the effects of the two secretagogues can be noted in chloride lumen-to-plasma flux, which was reduced in response to CT, whereas the reduction with VIP was not statistically significant. As expected, VIP and CT differed markedly with regard to the time course of their respective effects. CT administered intraluminally did not cause any change in PD for at least $2 \mathrm{~h}$ after its administration. Then the lumen negative PD increased to reach a new base line some 5-6 h later (Fig. 2).

Lumen-to-plasma concentration and electrical gradients (Tables I and II) revealed that chloride and bicarbonate were secreted actively in response to CT. Analysis of flux ratios (Table III) also suggested active chloride secretion. Although the flux ratios for sodium showed a tendency toward active secretion in response to CT, this was not statistically significant, as opposed to the results with VIP (where observed and calculated flux ratios were significantly different). 
TABLE II

Electrolyte Concentration in Plasma and Perfusate

\begin{tabular}{|c|c|c|c|c|c|c|c|c|c|}
\hline & \multicolumn{3}{|c|}{$\left[\mathrm{Na}^{+}\right]$} & \multicolumn{3}{|c|}{$\left[\mathrm{Cl}^{-}\right]$} & \multicolumn{3}{|c|}{$\left[\mathrm{HCO}_{3}^{-}\right]$} \\
\hline & \multirow[b]{2}{*}{ Plasma } & \multicolumn{2}{|c|}{ Lumen } & \multirow[b]{2}{*}{ Plasma } & \multicolumn{2}{|c|}{ Lumen } & \multirow[b]{2}{*}{ Plasma } & \multicolumn{2}{|c|}{ Lumen } \\
\hline & & $0 \mathrm{~min}$ & $60 \mathrm{~min}$ & & $0 \mathrm{~min}$ & $60 \mathrm{~min}$ & & $0 \mathrm{~min}$ & $60 \mathrm{~min}$ \\
\hline & & & & & mequliter & & & & \\
\hline Control & $156.7 \pm 4.3$ & $135.9 \pm 0.8^{*}$ & $138.2 \pm 0.6^{*}$ & $111.9 \pm 2.9$ & $113.5 \pm 2.0$ & $117.3 \pm 2.1 \ddagger$ & $20.6 \pm 2.3$ & $22.5 \pm 1.8$ & $22.0 \pm 1.5$ \\
\hline VIP & $155.1 \pm 2.9$ & $136.5 \pm 1.2^{*}$ & $140.9 \pm 1.2^{*}$ & $111.0 \pm 2.8$ & $113.7 \pm 1.5$ & $116.5 \pm 1.7 \S$ & $19.0 \pm 1.9$ & $23.1 \pm 1.7$ & $24.7 \pm 1.7 \ddagger$ \\
\hline Control & $154.8 \pm 5.6$ & $135.4 \pm 0.7^{*}$ & $138.7 \pm 0.6 \ddagger$ & $112.9 \pm 2.3$ & $113.2 \pm 1.6$ & $116.0 \pm 1.9$ & $17.0 \pm 1.4$ & $22.8 \pm 1.7$ & $22.6 \pm 1.9$ \\
\hline Control & $151.8 \pm 3.9$ & $138.9 \pm 0.9 *$ & $141.4 \pm 1.1^{*}$ & $106.7 \pm 1.8$ & $107.4 \pm 1.7$ & $109.0 \pm 2.0$ & $20.2 \pm 1.6$ & $21.9 \pm 0.9$ & $22.3 \pm 2.0$ \\
\hline CT $2-3 \mathrm{~h}$ & $152.0 \pm 3.3$ & $140.4 \pm 1.6^{*}$ & $142.6 \pm 1.8^{*}$ & $111.2 \pm 1.3$ & $113.9 \pm 2.4$ & $114.2 \pm 3.1$ & $20.2 \pm 1.3$ & $21.0 \pm 0.9$ & $24.6 \pm 1.5^{*}$ \\
\hline CT 6-7 h & $149.1 \pm 2.4$ & $138.4 \pm 1.0^{*}$ & $139.7 \pm 1.1^{*}$ & $108.5 \pm 2.6$ & $110.0 \pm 1.3$ & $112.0 \pm 2.3$ & $20.2 \pm 2.1$ & $23.3 \pm 1.3$ & $25.8 \pm 1.7^{*}$ \\
\hline
\end{tabular}

Values are mean \pm SEM of 10 loops (five dogs). Electrolyte concentrations were measured after 15 -min equilibration $(0$ min) and at the end of the perfusion periods $(60 \mathrm{~min})$. Statistical significance is determined for the difference between concentration in lumen and plasma.

$* P<0.01$.

$\ddagger P<0.05$.

$\$ P<0.02$.

Protein output into the perfusate was not increased by CT (Table IV), and no histological changes were found on light microscopy (Table V).

$P D$ and water movement. Fig. 5 illustrates the relation between net water movement and transmucosal $\mathrm{PD}$, including all data obtained during control periods and in response to VIP and CT administration. Curve fitting by the method of least squares using available interactive computing programs showed that a para- bolic curve gave the best correlation $(y=-3.137$ $\left.-0.201 x+0.002 x^{2}, r=0.839\right)$. High correlation coefficients were also found by linear $(r=0.812)$ and exponential $(r=0.775)$ regression analysis.

\section{DISCUSSION}

Effect of VIP. The major purpose of the present study was to examine in greater detail than previous

TABLE III

Observed and Calculated Flux Ratios of $\mathrm{Na}^{+}$and $\mathrm{Cl}^{-}$

\begin{tabular}{|c|c|c|c|c|c|c|}
\hline & $\begin{array}{c}\text { Initial } \\
\text { control } \\
\text { perfusion }\end{array}$ & $\begin{array}{c}\text { VIP } \\
\text { infusion }\end{array}$ & $\begin{array}{c}\text { Final } \\
\text { control } \\
\text { perfusion }\end{array}$ & $\begin{array}{l}\text { Control } \\
\text { perfusion }\end{array}$ & $\begin{array}{c}\text { Perfusion } \\
2-3 \mathrm{~h} \\
\text { after CT }\end{array}$ & $\begin{array}{l}\text { Perfusion } \\
6-7 \mathrm{~h} \\
\text { after CT }\end{array}$ \\
\hline \multicolumn{7}{|l|}{$\mathrm{Na}^{+}$} \\
\hline Observed & $\begin{array}{r}1.65 \\
\pm 0.22\end{array}$ & $\begin{array}{r}0.327 \\
\pm 0.054\end{array}$ & $\begin{array}{r}1.32 \\
\pm 0.17\end{array}$ & $\begin{array}{r}1.482 \\
\pm 0.122\end{array}$ & $\begin{array}{r}1.087 \\
\pm 0.233\end{array}$ & $\begin{array}{r}0.414 \\
\pm 0.179\end{array}$ \\
\hline Calculated & $\begin{array}{r}0.87 \\
\pm 0.02\end{array}$ & $\begin{array}{r}0.772 \\
\pm 0.013\end{array}$ & $\begin{array}{r}0.88 \\
\pm 0.02\end{array}$ & $\begin{array}{r}0.922 \\
\pm 0.019\end{array}$ & $\begin{array}{r}0.836 \\
\pm 0.026\end{array}$ & $\begin{array}{r}0.758 \\
\pm 0.178\end{array}$ \\
\hline$P$ & $<0.01$ & $<0.001$ & $<0.05$ & $<0.005$ & NS & NS \\
\hline \multicolumn{7}{|l|}{$\mathrm{Cl}^{-}$} \\
\hline Observed & $\begin{array}{r}1.38 \\
\pm 0.27\end{array}$ & $\begin{array}{r}0.37 \\
\pm 0.05\end{array}$ & $\begin{array}{r}1.08 \\
\pm 0.15\end{array}$ & $\begin{array}{r}1.424 \\
\pm 0.410\end{array}$ & $\begin{array}{r}1.098 \\
\pm 0.363\end{array}$ & $\begin{array}{r}0.563 \\
\pm 0.312\end{array}$ \\
\hline Calculated & $\begin{array}{r}1.18 \\
\pm 0.27\end{array}$ & $\begin{array}{r}1.21 \\
\pm 0.03\end{array}$ & $\begin{array}{r}1.03 \\
\pm 0.02\end{array}$ & $\begin{array}{r}0.991 \\
\pm 0.022\end{array}$ & $\begin{array}{r}1.148 \\
\pm 0.040\end{array}$ & $\begin{array}{r}1.208 \\
\pm 0.032\end{array}$ \\
\hline$P$ & NS & $<0.001$ & NS & NS & NS & $<0.001$ \\
\hline
\end{tabular}

Values are mean \pm SEM of loops (five dogs). NS: no significant difference at the 0.05 level of confidence. The observed flux ratio is computed by (lumen-to-plasma flux):(plasma-to-lumen flux). The calculated flux ratio for passive ion movement is derived from the $\mathrm{PD}$ and ion concentration in plasma and lumen according to Ussing's equation (20). With limitations described in the text, a significant difference between observed and calculated flux ratio suggests active transport. 
TABLE IV

Protein Output into the Lumen of Perfused Jejunal Loops

\begin{tabular}{ccc}
\hline Initial control & VIP & Final control \\
$180 \pm 32$ & $420 \pm 76^{*}$ & $288 \pm 44$ \\
\hline Initial control & CT 2-3 h & CT 6-7 h \\
$152 \pm 32$ & $144 \pm 32$ & $208 \pm 36$ \\
\hline
\end{tabular}

All values are measured in micrograms per centimeter per hour. Values are mean \pm SEM for 10 loops (five dogs). Protein output is significantly higher during VIP periods as compared to control perfusion. In CT protein output is not significantly increased.

$* P<0.01$.

in vivo studies the effect of VIP on intestinal transport. VIP caused profound secretion of water accompanied by secretion of chloride, bicarbonate, sodium, and potassium, and increased the lumen negative PD.

The ability to record the PD allows us to state with confidence that net secretion of chloride and bicarbonate occurs against an electrochemical gradient, whereas sodium and potassium move in the direction of their electrochemical gradients. The rise in luminal concentration, above plasma values, rules out solvent drag as the major cause of the secretion of these an-

TABLE V

Histological Evaluation of Mucosal Biopsies

\begin{tabular}{lcccc}
\hline & Control & VIP & $\begin{array}{c}\text { CT } \\
(6-7 \mathrm{~h})\end{array}$ & $P$ \\
\hline $\begin{array}{l}\text { Epithelial integrity } \\
\quad \text { Median }\end{array}$ & 0.3 & 0 & 0.7 & 0.084 \\
$\quad$ Range & $0-1.3$ & $0-0.7$ & $0-1.3$ & \\
$\begin{array}{l}\text { Width of intracellular } \\
\text { spaces } \\
\quad \begin{array}{l}\text { Median } \\
\quad \text { Range }\end{array}\end{array}$ & 0.3 & 0 & 0.3 & 0.275 \\
$\begin{array}{l}\text { Diameter of mucosal } \\
\text { capillaries }\end{array}$ & $0-0.7$ & $0-0.3$ & $0-1.3$ & \\
$\quad \begin{array}{l}\text { Median } \\
\text { Range }\end{array}$ & 0.4 & 1.5 & 0.5 & $0.009 *$ \\
\hline
\end{tabular}

Values were obtained by Kruskal-Wallis one-way analysis of variance (18) entering the three groups (control, VIP, CT) of average results of each slide (i.e., mean score of three observers on each of 20 slides [20 loops] from control periods and 10 slides [10 loops] of VIP and CT [6-7 h] periods, respectively). The $P$ values indicate the probability that one could get a larger difference between the three groups by chance alone.

${ }^{*}$ Multiple comparisons showed that the estimated capillary diameter was significantly different at the 0.05 level of significance in biopsies taken from control and VIP periods. ions. The passive or active nature of ion secretion can be further tested by comparing the observed ratios of unidirectional fluxes for each ion with those calculated by substitution of ion concentrations (plasma and lumen) and PD into the Ussing equation. The significant difference between observed and calculated flux ratios for chloride confirms active secretion in response to VIP (Table III). In addition, analysis of flux ratios for sodium suggested active secretion in response to VIP.?

Thus, it would appear that VIP induces active anion secretion which creates an electrical gradient favoring the passive secretion of cations. In addition, there may be a component of active sodium secretion.

The PD response to SMA infusion of VIP occurred within $1 \mathrm{~min}$ (Fig. 2). Although electrical traces obtained from small and large intestine in vitro in response to VIP have shown a remarkable resemblance to our present records $(1,19)$, there are no previous measurements of transmural PD in response to VIP in vivo. The prompt $P D$ response might suggest easy access and(or) high affinity of VIP to receptors.

We have also examined histological sections and protein output to look for evidence of filtration as an additional cause of intestinal secretion (20-22). The histologic finding of capillary dilatation and increased protein output into the lumen favor a hemodynamic effect. (These were reversible and therefore presumably did not indicate tissue damage.) However, the intercellular spaces were tightly closed during VIP-induced secretion, which is opposite to what would be expected if secretion were due to filtration in response to increased mucosal tissue pressure (21). Therefore, these results are somewhat contradictory and do not clearly support nor refute a component of filtration flow as an accessory mediator of the secretory response to VIP.

Similarity of VIP-and CT-induced secretion. In the present study we used the same in vivo experimental model to compare jejunal secretion induced by VIP and CT. The results obtained show striking similarity. Both agents cause active chloride and bicarbonate secretion. Chloride lumen-to-plasma fluxes were decreased, but only in response to CT was this statistically significant. Analysis of flux ratios suggested a component of active sodium secretion in response to VIP and a similar tendency, although statistically not significant, in response to CT. The most striking difference between the two agents was the time course of

\footnotetext{
${ }^{7}$ In spite of the fact that determination of flux ratios has been of considerable value in elucidating ion movements in vitro, some caution is necessary in their interpretation in vivo. For example, the Ussing equation takes no account of solventlinked ion transport and local ion concentrations within unstirred layers. Furthermore, the determination of plasma-tolumen flux of ion by subtraction of lumen-to-plasma flux from net flux may be subject to error. Therefore, conclusions based solely on flux ratio analysis cannot be considered to be definitive.
} 


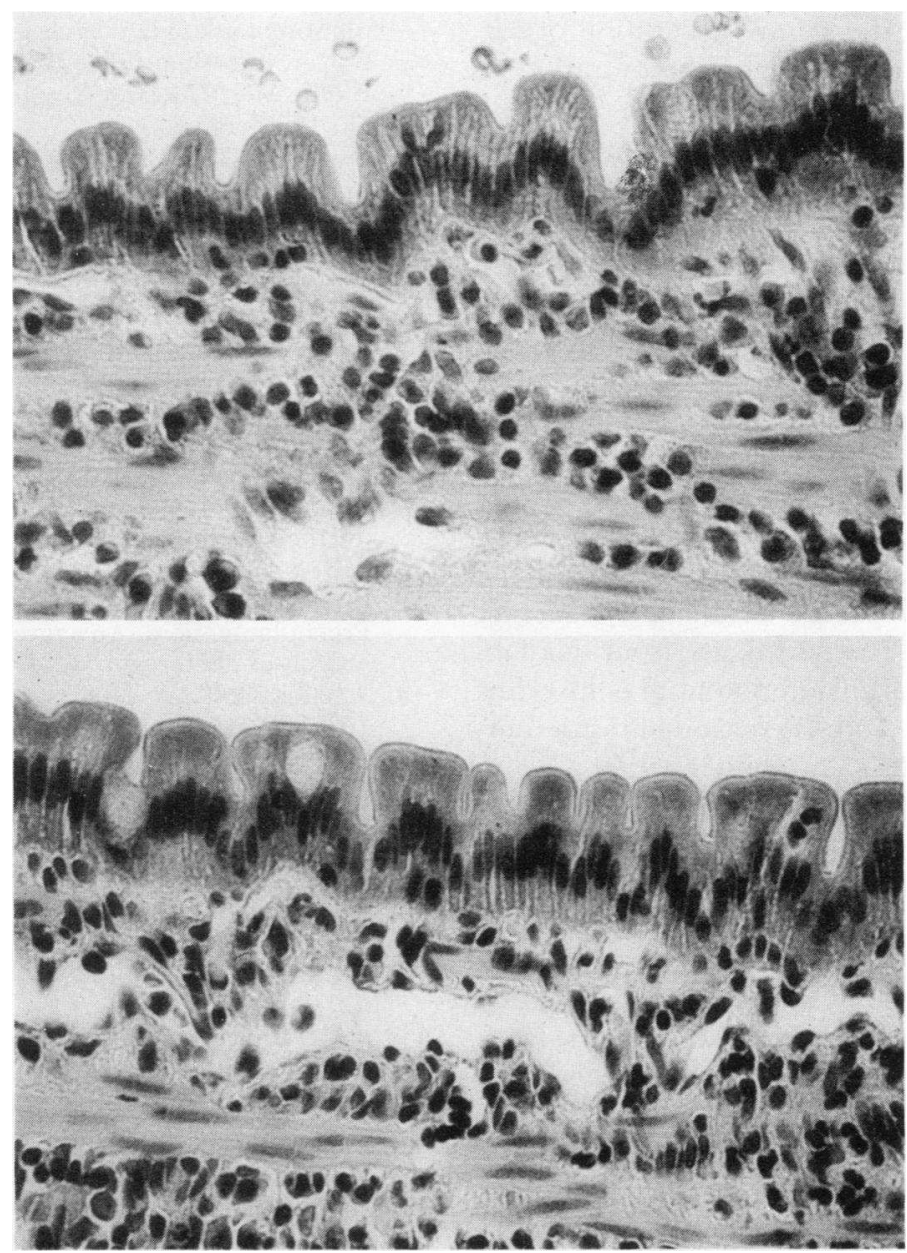

Figure 4 Jejunal mucosa near villus tip $(H \& E \times 160)$ after control period (top) and VIP period (bottom). VIP did not cause any epithelial alterations, and the intercellular spaces were not widened. The capillaries, however, were dilated in response to VIP. The capillary dilatation was readily reversible. It was not seen on biopsies from the final control period.

their respective actions. For example, as opposed to the immediate PD increase in response to VIP, no change in PD was recognizable during the first $2 \mathrm{~h}$ after exposure of the loops to CT.

It seems likely that a common secretory mechanism could accomodate the small differences in secretion induced by the two agents, and there is evidence that activation of the adenylate cyclase-cyclic AMP system occurs with both agents. The differences in time course of the secretions may reflect different times required for access to receptors, different affinity to receptors, or different intermediate steps at which the secretory process is triggered.

PD and water movement in the dog jejunum. Our data show a significant correlation between the magnitude of the PD and the secretion of water (Fig. 5). It seems likely from examination of ion fluxes that this relationship is mediated by the active electrogenic secretion of anions. Such a mechanism would establish

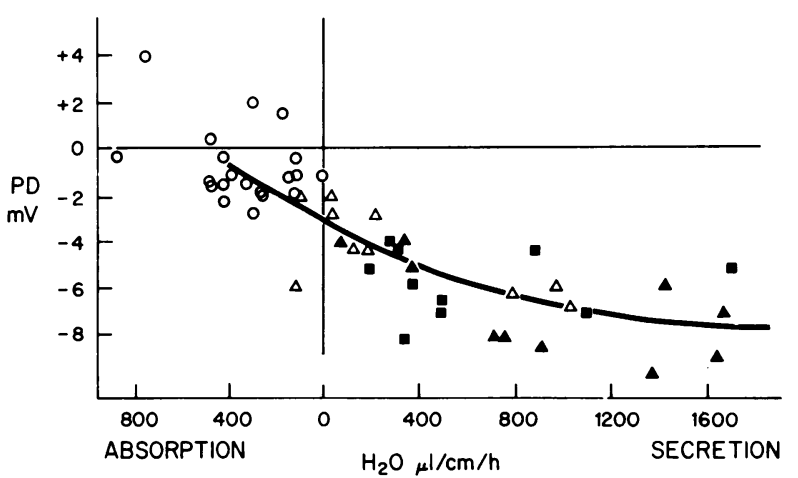

Figure 5 Relation between net water movement (abscissa) and transmucosal PD (ordinate). Symbols: $\bigcirc$ basal, $\mathbf{\square}$ VIP, $\triangle \mathrm{CT}(2-3 \mathrm{~h}), \Delta \mathrm{CT}(6-7 \mathrm{~h})$. The parabolic curve $(y=-3.137$ $\left.-0.201 x+0.002 x^{2}\right)$ found by the method of least squares (computer curve fitting) gave the best correlation $(r=0.839)$, suggesting that the PD cannot become more negative at higher secretion rates, probably as a result of the permeability characteristics of jejunal mucosa (see Discussion). 
an electrical gradient for the passive secretion of cations, while development of a high concentration of ions at the site of secretion (within crypts or within villous unstirred layer) would promote osmotic flow of water from plasma to lumen.

Inspection of Fig. 5 shows that although the PD becomes progressively more negative in proportion to secretion at low rates of secretion, at high rates it levels off and is independent of secretion rate. Mathematical analysis confirms that a curvilinear fit gave the highest correlation coefficient (parabolic curve in Fig. 5). There are several theoretical explanations for this observation. First, an absolute increase in anion permeability at high secretion rates would allow increased anion back leak (lumen to plasma) with dissipation of the PD. The observation by Moore et al. (23) (recently confirmed in unpublished experiments from our laboratory) that the sodium diffusion potential is lost during cholera is compatible with increased chloride permeability, as are Powell's data showing that CT increases the ratio of chloride to sodium permeability (24). Second, an increase in cation permeability would reduce the observed PD for any given amount of electrogenic anion secretion. This second possibility would run counter to the evidence of Moore et al. and Powell, and both the first and second suggestions (especially the second) are difficult to reconcile with a large amount of data suggesting that passive permeability in cholera is reduced instead of increased $(25,26)$.

A third possible explanation is that at high secretion rates active electrogenic sodium secretion might come into play, and thus reduce the PD that otherwise would have resulted from electrogenic anion secretion. Our flux ratio data suggest the possibility of active sodium secretion, although firm conclusions about active vs. passive transport cannot be made from analysis of flux ratio analysis alone. It will require further work to decide which, if any, of these three factors is the explanation for the failure of PD to continue to increase at higher rates of secretion.

\section{ACKNOWLEDGMENTS}

The assistance of Kim Bain, Dr. Richard Browne, William Fordtran, Jean Harber, Vicki Jones, Gertrud Krejs, Stephen Morawski, Dr. Maria Read, Dr. Joan Reisch, and Carol Santa Ana is gratefully acknowledged.

This study was supported by research grant 5-R01-AM06506 from the National Institute of Arthritis, Metabolism, and Digestive Diseases, and by Southwestern Medical Foundation, Dallas, Tex.

\section{REFERENCES}

1. Schwartz, C. J., D. V. Kimberg, H. E. Sheerin, M. Field, and S. I. Said. 1974. Vasoactive intestinal peptide stim- ulation of adenylate cyclase and active electrolyte secretion in intestinal mucosa. J. Clin. Invest. 54: 536-544.

2. Field, M. 1974. Intestinal secretion. Gastroenterology. 66: 1063-1084.

3. Barbezat, G. O. 1973. Stimulation of intestinal secretion by polypeptide hormones. Scand. J. Gastroenterol. 8 (Suppl. 22): 1-21.

4. Makhlouf, G. M., and S. I. Said. 1975. The effect of vasoactive intestinal peptide (VIP) on digestive and hormonal function. In Gastrointestinal Hormones. J. C. Thompson, editor. University of Texas Press, Austin. 599-610.

5. Coupar, I. M. 1976. Stimulation of sodium and water secretion without inhibition of glucose absorption in the rat jejunum by vasoactive intestinal peptide. Clin. Exp. Pharmacol. Physiol. 3: 615-618.

6. Finkelstein, R. A., and J. J. LoSpalluto. 1970. Production, purification and assay of cholera toxin. J. Infect. Dis. 121: S63-S72.

7. Finkelstein, R. A., K. Fujita, and J. J. LoSpalluto. 1971. Procholeragenoid: An aggregated intermediate in the formation of choleragenoid. J. Immunol. 107: 1043-1051.

8. Schafer, D. E., W. D. Lust, B. Sircar, and N. D. Goldberg. 1970. Elevated concentrations of adenosine $3^{\prime}: 5^{\prime}$-cyclic monophosphate in intestinal mucosa after treatment with cholera toxin. Proc. Natl. Acad. Sci. U. S. A. 67: 851856.

9. Sharp, G. W. G. 1973. Action of cholera toxin on fluid and electrolyte movement in the small intestine. Annu. Rev. Med. 24: 19-28.

10. Pierce, N. F., W. B. Greenough II, and C. C. Carpenter. 1971. Vibrio cholerae enterotoxin and its mode of action. Bacteriol. Rev. 35: 1-13.

11. Read, N. W., R. M. Smallwood, R. J. Levin, C. D. Holdsworth, and B. H. Brown. 1977. Relationship between changes in intraluminal pressure and transmucosal potential difference in the human and canine jejunum in vivo. Gut, 18: 141-151.

12. Fordtran, J. S., R. Levitan, V. Bikerman, B. A. Burrows, and F. J. Ingelfinger. 1961. The kinetics of water absorption in the human intestine. Trans. Assoc. Am. Physicians Phila. 74: 195-205.

13. Levitan, R., J. S. Fordtran, B. A. Burrows, and F. J. Ingelfinger. 1962. Water and salt absorption in the human colon. J. Clin. Invest. 41: 1754-1759.

14. Krejs, G. J., L. L. Seelig, and J. S. Fordtran. 1977. Effect of protonated 2,4,6-triaminopyrimidine, a "tight junction blocker," on intestinal transport in dog ileum in vivo. Gastroenterology. 72: 685-691.

15. Berger, E. Y., and J. M. Steele. 1958. The calculation of transfer rates in two compartment systems not in dynamic equilibrium. J. Gen. Physiol. 41: 1135-1152.

16. Ussing, H. H. 1950. The distinction by means of tracers between active transport and diffusion. The transfer of iodide across the isolated frog skin. Acta Physiol. Scand. 19: 43-56.

17. Lowry, O. H., N. J. Rosebrough, A. L. Farr, and R. J. Randall. 1951. Protein measurement with the Folin phenol reagent. J. Biol. Chem. 193: 265-275.

18. Siegel, S. 1956. Kruskal-Wallis one-way analysis of variance. In Nonparametrical Statistics. McGraw-Hill, Inc., New York, Toronto, and London. 184-193.

19. Racusen, C., and H. J. Binder. 1977. Alteration of large intestinal electrolyte transport by vasoactive intestinal polypeptide in the rat. Gastroenterology. 73: 790-796.

20. Yablonski, M. E., and N. Lifson. 1976. Mechanism of production of intestinal secretion by elevated venous pressure. J. Clin. Invest. 57: 904-915. 
21. DiBona, D. R., L. C. Chen, and G. W. G. Sharp. 1974. A study of intercellular spaces in the rabbit jejunum during acute volume expansion and after treatment with cholera toxin. J. Clin. Invest. 53: 1300-1307.

22. Makhlouf, G. M. 1977. Distinct mechanisms for stimulation of intestinal secretion by vasoactive intestinal peptide (VIP) and glucagon. Gastroenterology. 72: 368-369.

23. Moore, W. L., F. A. Bieberdorf, S. G. Morawski, and J. S. Fordtran. 1971. Ion transport during cholera-induced ileal secretion in the dog. J. Clin. Invest. 50: 312-318.
24. Powell, D. W. 1974. Intestinal conductance and permselectivity changes with theophylline and choleragen. Am. J. Physiol. 227: 1436-1443.

25. Powell, D. W., H. J. Binder, and P. F. Curran. 1973. Active electrolyte secretion stimulated by choleragen in rabbit ileum in vitro. Am. J. Physiol. 225: 781-787.

26. Hendrix, T. R., and H. T. Paulk. 1977. Intestinal secretion. In International Review of Physiology, Gastrointestinal Physiology II, Vol. 12. R. K. Crane, editor. University Park Press, Baltimore. 257-284. 